During the first trial, we examined the postprandial amino acid composition of the contents collected during I 2 consecutive hours. The samples collected during 3 hours were pooled together. The ro p. Ioo trichloracetic acid soluble fraction was separated from the residue. The extracts and residues were then hydrolyzed by $6 \mathrm{~N}$ hydrochloric acid for the amino acid determination. Variations in the amino acid compositions during the day are low, especially as regards the extraction residues. The amino acid compositions of the acidosoluble fractions are not very different from those of the extraction residues, in contrast to what is observed in the ingested food. However, nitrogenous compounds of the extracts contain more glutamic acid, and consecutively less of most of the other amino acids than those of the residues.

Moreover, we studied the amino acid composition of the nitrogenous matter of the duodenum contents of cattle receiving diets differing widely one from the other (maize-urea silage, hay-barley-urea, and grass). The total amino acid compositions determined after hydrolysis of the samples are similar for the three kinds of diets. However, the duodenum contents of the animals which received diets with urea, contain more phenylalanine and glutamic acid. The Iysine content is identical for all the diets, but its proportion among the other amino acids is slightly higher in the case of the grass diet than for the other diets.

The amounts of nitrogenous matter leaving the abomasum may vary during the day, but their amino acid composition remains fairly constant even with very different diets, a fact which shows the importance of the regulatory role of the rumen.

\title{
UTILISATION COMPARÉE DU CARBONATE ET DU SULFATE DE CALCIUM CHEZ LE MOTTON
}

\author{
L. GUÉGUEN et P. BESANÇON \\ Station de Recherches de Nutrition, \\ Centre national de Recherches zootechniques, I. N. R. A., \\ 78 - Jouy-en-Josas
}

L'expérience que nous rapportons fait partie d'un programme général de recherches sur l'influence de divers facteurs alimentaires sur le métabolisme phospho-calcique chez l'animal et fournit les premiers résultats d'une étude portant sur l'influence des sulfates.

L'emploi de plus en plus fréquent de régimes à base d'ensilage de mais et d'urée chez les ruminants nécessite un supplément de soufre et de calcium et l'apport de sulfate de calcium pourrait être envisagé. Chez l'Homme, ce sel serait très mal absorbé (LeSTradeT, 1962). En fait, il a été démontré chez le Rat (CAUSERET et Hugot, I958) que l'absorption du calcium ainsi fourni était normale mais que l'excrétion urinaire était accrue, sans toutefois diminuer le bilan calcique.

Le présent essai a porté sur 3 moutons mâles pesant de 50 à $60 \mathrm{~kg}$, recevant une ration de base pauvre en calcium ( $\mathrm{I} g$ par $\mathrm{kg}$ de matière sèche), supplémentée soit avec $\mathrm{CaCO}_{3}$, soit avec $\mathrm{CaSO}_{4}$. Les aliments ainsi complétés contenaient en moyenne $5 \mathrm{~g}$ de $\mathrm{Ca}, 3,8 \mathrm{~g}$ de $\mathrm{P}$ et $\mathrm{I}, 2$ ou $4 \mathrm{~g}$ de $\mathrm{S}$ par $\mathrm{kg}$. Pour chaque régime, deux périodes de bilans de ro jours ont été réalisées, dont une avec dilution isotopique $\left({ }^{45} \mathrm{Ca}\right)$.

Les coefficients d'utilisation digestive réelle (CUDr) de Ca sont de 23,8 p. Ioo pour le car- 
bonate et de $2 \mathrm{I}, 8 \mathrm{p}$. IOO pour le sulfate, mais l'élimination urinaire de Ca est 5 fois plus forte avec le sulfate $(0,95$ contre $0,2 \mathrm{I} g$ par jour). Ainsi, le sulfate de calcium, bien que normalement absorbé, conduit à un bilan négatif de $\mathrm{Ca}(-0,79 \mathrm{~g}$ contre o,ı $\mathrm{g}$ par jour) et de $\mathbf{P}(-\mathbf{0 , 4} \mathrm{g}$ contre $0,70 \mathrm{~g}$ par jour).

L'excrétion fécale de calcium endogène est la même dans les deux cas, soit 21 et $22 \mathrm{mg}$ de $\mathrm{Ca}$ par $\mathrm{kg}$ de poids vif et par jour. L'action primaire des ions $\mathrm{SO}_{4}{ }^{--}$semble donc bien se situer au niveau rénal, probablement en diminuant la réabsorption tubulaire du calcium.

Les pertes endogènes fécales et le CUDr du calcium ainsi obtenus dans les deux essais sont très inférieurs aux valeurs moyennes couramment adoptées pour calculer les besoins en calcium du Mouton, mais sont en parfait accord avec les résultats d'autres travaux récents. Il semble donc que l'utilisation digestive du calcium chez le Ruminant adulte soit souvent surestimée.

\section{SUMMARY}

\section{COMPARATIVE, UTILIZATION OF CALCIUM CARBONATE AND CALCIUM SUI.PHATE IN THE SHEEP}

The experiment reported in the present paper is part of a general research programme dealing with the influence of various feeding factors upon the phospho-calcic metabolism in the animal; the first results of a study on the influence of sulphates are given in this report.

The more and more frequent utilization of diets containing maize silages and urea in rumi nants necessitates sulphur and calcium supplementation and the possibility of using calcium sulphate has been studied. It seems that, in human beings, this salt is very badly absorbed (Lestradet, I962). In fact, it has been shown in the rat (CAUSERET and Hugot, 1958), that the absorption of calcium, supplied in this form, was normal, but that the urinary excretion increased without diminishing, however, the calcic balance.

The present trial was carried out with 3 male sheep, between 50 and $60 \mathrm{~kg}$, receiving a basal diet poor in calcium ( $\mathrm{I} \mathrm{g} / \mathrm{kg}$ dry matter) supplemented either by $\mathrm{CaCO}_{3}$ or by $\mathrm{CaSO}_{4}$. The feed supplemented in this way contained, on an average, $5 \mathrm{~g} \mathrm{Ca}, 3.8 \mathrm{~g} \mathrm{P}$ and 1.2 or $4.0 \mathrm{~g} \mathrm{~S}$ per $\mathrm{kg}$. Two balance periods of Io days, the one with isotopic dilution $\left({ }^{45} \mathrm{Ca}\right)$, were realized for each diet.

The real digestive utilization coefficients (CUDr) of $\mathrm{Ca}$ are $23.8 \mathrm{p}$. Ioo for carbonate and 2 r. 8 p. Ioo for sulphate, but the urinary elimination of $\mathrm{Ca}$ is 5 times higher with sulphate ( 0.95 versus $0.21 \mathrm{~g}$ per day). Thus, calcium sulphate, although normally absorbed, gives a negative balance of $\mathrm{Ca}$ ( $-0.79 \mathrm{~g}$ versus $0.10 \mathrm{~g}$ per day) and of $\mathrm{P}(-0.40 \mathrm{~g}$ versus $0.70 \mathrm{~g}$ per day).

The faecal excretion of endogenous calcium is the same in the two cases, i.e. 21 and $22 \mathrm{mg}$ $\mathrm{Ca}$ per $\mathrm{kg}$ live weight per day. Consequently, the primary action of the $\mathrm{SO}_{4}-$-ions seems to be localized at the renal level, consisting probably in a decrease of the tubular reabsorption of calcium.

The faecal endogenous losses and the CUDr of calcium, obtained during the two trials, are much lower than the mean values generally used to calculate the calcium requirements of sheep, but are in absolute agreement with the results of other recent researches. Thus, it seems that the digestive utilization of calcium in ruminants is often overestimated. 